Чорна Н.М., д. i. н., доu. Вінницький торговельно-економічний інститут КНТЕУ, м. Вінниця, Україна Google Scholar https://scholar.google.com.ua/citations?hl=uk\&user=YB22PJwAAAAJ

\title{
КЛАСТЕРНІ ІНЦЦАТИВИ ЯК ЗАПОРУКА РОЗВИТКУ СІЛЬСЬКОГО ЗЕЛЕНОГО ТУРИЗМУ
}

У XVIII ст. як явище зародившись у французьких і швейцарських Альпах, в повоєнний період набувши значного поширення в багатьох європейських країнах, в 1990-х рр. сільський зелений туризм отримав передумови для розвитку в Україні.

Упродовж останніх років, з огляду на брак державного фінансування та традиційно невелику зацікавленість бізнесових структур в інвестиціях у сільські території, сільський зелений туризм остаточно укріпився в якості своєрідної панацеї, спроможної забезпечити віднайдення нових джерел та механізмів забезпечення економічного зростання традиційно депресивного українського села, підвищення рівня життя його мешканців, більшої їх забезпеченості матеріальними та духовними благами.

В умовах триваючого збройного конфлікту на Сході України, коли вкрай важливою $є$ активізація патріотичних настроїв, відродження українського села, яке споконвіку виконує поважну місію збереження традицій та звичаїв українського народу, його культурної самобутності та менталітету, набуває неабиякого значення. Значну актуальність в контексті вказаного має, відтак, розвиток на селі зеленого туризму, характерного самозайнятістю населення, орієнтацією на мінімальні інвестиції та забезпеченістю на належному рівні необхідними туристично-рекреаційними ресурсами.

Попри те, що сільський зелений туризм як явище зародився в Україні наприкінці XIX ст., на новий етап розвитку він вийшов в 1996 р., у зв’язку з утворенням ГО «Спілка сільського зеленого туризму України» (далі - Спілка) [1]. У 2003 р. поняття «сільський зелений туризм» вперше зазнало законодавчого закріплення [2].

На сьогодні найбільш перспективним напрямом розвитку в Україні сільського зеленого туризму є створення та функціонування туристичних кластерів. Представлені концентрацією на певній території підприємств індустрії туризму, які 3 метою створення 
туристського продукту взаємодіють між собою, спільно використовуючи туристські ресурси, інфраструктуру, ринок праці, кластерні ініціативи вже впродовж тривалого часу характеризують розвиток туристичної галузі України і їх популярність стрімко зростає.

Аналіз існуючих кластерів дозволяє констатувати три основні моделі їх функціонування:

- садибна, яка базується на об’єднаній діяльності садиб та закладів гастрономічно-розважального типу, які надають послуги харчування, розміщення та дозвілля (кластери «Оберіг» (смт Гриців Хмельниччини), «Бойківські газди» (Сколівський р-н Львівщини), «Гостинна бойківська Долинщина» (Долинський p-н ІваноФранківщини);

- агротуристична, яка базується на виробничій діяльності фермерських підприємств та домогосподарств, для яких рекреаційнотуристичні послуги виступають як додаткові (кластери «ФрумушикаНова» (Тарутинський район Одещини), «ГорбоГори» (Пустомитівський район Львівщини);

- локального туристичного продукту, пов’язана з пропозицією туристичного продукту на базі туристичних атракцій регіону, серед яких - історичні об'єкти, заклади культури, заклади розміщення (кластери «Мальовнича Бережанщина» (Тернопільська обл.), «Гоголівськими місцями Полтавщини» (Полтавська обл.) [3].

Згідно з інформацією Спілки, станом на 01.03.2018 р. в Україні функціонували десять сільських туристичних кластерів, успіхи діяльності яких забезпечували регіонам економічний та соціокультурний розвиток. Та, беручи до уваги започаткування влітку 2018 р. спільної платформи «Туристичні кластери 300+», метою якої $\epsilon$ створення впродовж найближчих трьох років 300 туристичних кластерів, маємо підстави очікувати на появу нових кластерних ініціатив, в тому числі в сфері сільського зеленого туризму.

Як засвідчує вітчизняний та зарубіжний досвід, розвиток туристичних (агротуристичних, агрорекреаційних і агроекологічних) кластерів спроможний суттєво сприяти збільшенню в’їзного та внутрішнього туристичного потоку, а, отже, і стійкому та всебічному економічному зростанню України.

\section{Список бібліографічних посилань}

1. Офіційний сайт ГО «Спілка сільського зеленого туризму України». URL: https://www.greentour.com.ua/ 
2. «Про особисте селянське господарство» : Закон України від 15 травня 2003 p. URL: https://zakon.rada.gov.ua/laws/show/742-15

3. Проект «Сільський зелений туризм - від роз'єднаних садиб до територіальних кластерів». URL: https://www.greentour.com.ua/ projects/proekt_agrosilrozvutok 